By ROBERT H. MULLER

\title{
College Library Buildings Self-Appraised
}

Dr. Muller is librarian, Bradley University.

TEAS on library buildings are undergoing $I_{\text {a }}$ revolution. Libraries are being planned from the inside out. The emphasis is on function as against monumentality. Flexibility is the keyword. Stacks and reading areas will be interchangeable. Ceiling heights will be lowered. Expansion will be provided for. New mechanical devices will be installed. The library will be a comfortable and attractive place for readers and librarians.

Yet there are obstacles. Boards of trustees and donors have a peculiar tendency to look to the past for models. They are not eager to be trail blazers for modern design. Many of them still think of the library as a showpiece for out-of-town visitors, an impressive campus landmark.

When it comes to planning a new library, the tendency is to copy the features of other library buildings, memories of which happened to linger in the mind of some board or faculty member. It may be an outdoor reading area, an impressive reference room, a cozy browsing room, or a particular style of exterior architecture. Such features are then transplanted into the new setting. It is always safer to adopt a standard pattern than to try something new, especially when the new exists only in blueprints.

The skeptic is bound to ask: Are our present buildings really completely inadequate? Isn't there anything at all to be learned from the past? Aren't there some librarians who are perfectly satisfied with many features of their present buildings? With such questions in mind, an opinion survey was undertaken under the sponsorship of the A.C.R.L. Committee on College and University Library Buildings. A brief question blank was mailed to all the thirty-five colleges that were known to have completed new library buildings during the past ten years. All but two responded. ${ }^{1}$

The aim of the survey was to obtain personal appraisals of college library architecture and to find out how well satisfied librarians were with their new buildings. The question blank asked: If you could have your building built over again, (I) What would you have in it that is now lacking? (2) What features of your present building would you wish to see eliminated? (3) What features do you consider so indispensable that you would insist on having them incorporated in any new building? The questions were designed to encourage free expression of opinion.

1 Albion College, Bennett College, Brooklyn College, University of California College of Agriculture, Colby College, Texas College of Mines and Metallurgy, Carroll College, Colorado State College of Education, Denison University, Drake University, Drew University, Eastern Washington College of Education, Franklin and Marshall College, George Pepperdine College, Georgia State Womens College, Illinois State Normal University, MacMurray College for Women, Madison College, Manhattanville College of the Sacred Heart, Milwaukee-Downer College, College of New Rochelle, Pennsylvania State College, Rhode Island State College, Rockford College, St. Bonaventure College, Salem College, San Jose State College, Skidmore College, South East Missouri State Teachers College, Southern Methodist University, Western State College of Colorado, University of Wichita, Willamette University. 
Most of the answers deal with individual aspects or components of existing buildings. In only four instances do respondents criticize the basic plan of an entire building as being insufficiently flexible. Thus it appears that the occupants of recently completed buildings of traditional design are either unfamiliar with or (although less likely) antagonistic to the latest trends in library planning as presented, for instance, in the meetings of the Cooperative Committee on Library Building Plans since 1944. It is not surprising to find that librarians who occupy new buildings do not pay much attention to the latest discussions. They are not charged with the responsibility of planning a new building. Their present buildings were planned largely to meet the needs of the present and to provide for the expansion of their book collections. It is to be expected, therefore, that many of the buildings are quite satisfactory for present requirements and are felt to be deficient merely in minor details. Only when the composition and character of the student body, the curriculum, the faculty, and the library staff change does it become apparent that existing buildings are basically unsatisfactory. And such radical changes are not likely to occur within a short span of ten years. If we were to conduct a survey of buildings twenty-five to thirty-five years old, we should expect much sharper criticism of basic plans and designs.

The answers to our survey are briefly summarized under the following headings: (I) over-all features, (2) space relationships, (3) rooms for special uses, (4) stacks, and (5) equipment.

\section{Over-All Features}

Noise control was found to be unsatisfactory in eleven libraries, especially in corridors and delivery halls. Ventilating shafts and grills make noise control diffcult. One librarian suggested that soundproofing material should be applied not merely on ceilings but also at least halfway down the side walls. Lavatories in libraries should be soundproofed if they are located close to reading rooms.

In three libraries, there were no doors or partitions between corridors and reading rooms, so that traffic noise tended to disturb readers. Glass partitions appear to be most satisfactory. (Examples: Carroll College and Southern Methodist University.) Satisfactory soundproofing was reported by Rhode Island State College and San Jose State College.

Air conditioning is second on the list of desiderata, with nine librarians wishing they had it. In two of these libraries, part of the building (e.g., the stacks) had no air conditioning. Such a division was reported to be unsatisfactory. As to the heating systems, both steam radiators and forced hot air failed to be satisfactory. Albion College reported favorably on its air-circulatory system and automatic heat control. In libraries where air conditioning had been installed, it was found to be a good feature. (San Jose State College and University of California College of Agriculture.)

Poor lighting was reported by six librarians. Three of them desired fluorescent fixtures. Complete satisfaction with their present lighting system was expressed by the librarians of Skidmore College, San Jose State College, University of California College of Agriculture, and Manhattanville College. The first two of these libraries have fluorescent lighting. The use of glass brick and wide plate glass windows to permit fuller utilization of daylight was found to be undesirable on south and southwest exposures in two libraries. 
Work space for the library staff was found inadequate in eight libraries. In general, sufficient space seems to have been provided for the catalog department, but not enough for circulation, reference, and periodical work.

Ground-level loading, with a driveway leading to the back door, was desired by three librarians. If the catalog office is not on the ground floor, an elevator should connect it with the receiving room.

Floor coverings were unsatisfactory in three libraries. Unfavorable comments were made about linoleum, marble, and asphalt tile. Rubber tile floors seemed preferable.

Sharing a building with the administration caused complaints in four libraries. In one library, an exhibition room of the art department located in the library tended to disturb library functions.

Decorative grand stairways were condemned by three librarians. Modern libraries will emphasize the functional aspects of stairways.

Small reading rooms seemed to aggravate the problem of supervision in two libraries. It was recommended that no reading room should accommodate fewer than I I 5 to 125 readers.

Miscellaneous features wanted by only a small number of librarians are briefly listed: more telephones, storage space for supplies, toilet facilities, reading room space, a pneumatic tube system, a public elevator, a large informal entrance lobby.

Undesirable features affecting only a few libraries are also listed without comment: memorial features, excessive hall space, long narrow reading rooms, low windows permitting no room for wall shelving in reading room.

Not all librarians were dissatified with their buildings. Here is what some of them liked particularly well: informality
(Skidmore College); windows from ceilings to floor (Southern Methodist University); ample telephone and buzzer systems (St. Bonaventure College); two stairways (Eastern Washington College of Education); provision for expansion (University of California College of Agriculture).

\section{Space Relationships}

The location of rooms and areas in relation to one another has a bearing on the efficiency of a building.

Central supervision is important when the library staff is too small for the building. Three librarians indicated that they would want a building that can be centrally supervised (examples: College of New Rochelle or Willamette University). Reading room areas should be visible from the circulation desk, preferably through plate glass partitions.

Accessibility of stacks from reading room areas was reported to be lacking in four libraries. Easy access from the reading rooms is particularly important where subject reading areas (divisional or departmental) are planned. Examples of buildings where such conversion is possible are the libraries of Drake University, the San Jose State College, and the Colorado State College of Education.

The public card catalog is located too far from the catalog and order departments in two libraries. One librarian reported that the location of the catalog near the stack entrance was found to be highly desirable.

Whether the main floor is to be on the first or second floor appears to be somewhat controversial. In the College of $\mathrm{New}$ Rochelle, location of the circulation desk and catalog on the second floor was reported to be very satisfactory; and in another college, location of the main service on the ground floor was found to be undesirable. At a third college, the circu- 
lation desk will soon be moved from the second to the first floor.

The location of the librarian's office is also a matter of controversy. Some librarians seem to like a somewhat secluded office, others prefer a location near the circulation desk. Much depends on the size of the library staff and the temperament of the librarian. If the librarian has a secretary, she should have a separate office adjoining the librarian's office. The entrance to the librarian's office should be from a hallway, not from a reading room.

The reading room entrance appears to have been poorly designed in only one library. In this library, there are two doors, one at each end, causing a traffic lane through the reading room. One door at the center is preferable.

\section{Rooms for Special Uses}

Librarians want a great variety of rooms which their libraries do not contain at present. The following tabulation shows, for each type of room or area, the number of librarians expressing a desire for it.

Projection and lecture room

Music listening room

Conference, seminar, study rooms

Staff lounge

Kitchenette (near staff lounge)

Photolaboratory

Typing room

Outdoor reading area

Room for rare or special collections

Separate reserve room

Quarters for library science students

Talking room

Faculty lounge

Microfilm reading space

Open-shelves reserve room

Smoking room

Bibliography room

Documents and pamphlet room

Periodical room

Faculty office

Coat check room

Locker room for student assistants
Some of the rooms reported to be indispensable in libraries are briefly listed here together with the names of the colleges: (I) lecture room, Southern Methodist University; (2) music listening room, San Jose State College; (3) seminar rooms, Willamette University and Pennsylvania State College; (4) conference-study rooms, Drew University and MacMurray College, (5) photolaboratory, Drew University; (6) typing room, Drake University; (7) outdoor reading area, Salem College; (8) microfilm reading room, Pennsylvania State College; (9) browsing room, Drew University and Western State College of Colorado.

\section{Stacks}

The most frequent complaint (five libraries) is that the stacks are not large enough. A library should not outgrow its stack space in less than ten years. As to stack enlargement, two librarians recommend vertical extensions, whereas a third prefers horizontal expansion. Stacks below ground level are condemned by two librarians.

More carrells are needed in four libraries. Wherever carrells are now installed, they are reported to be indispensable. One librarian suggested that carrells should be equipped with typewriters.

Book lifts, preferably electric ones, are next on the list, four libraries reporting this desideratum. Some libraries need more than one book lift or a book lift of larger size.

Elevators are not installed in two libraries, and a third one needs an additional elevator. Four libraries report that their stack elevators are absolutely indispensable.

Stairways are too narrow in three libraries. For open stacks, double approach stairways are recommended. Many college libraries have open stacks, providing easy 
access to all levels.

There are two libraries where stack levels and floor levels do not coincide, so that steps had to be built to connect the floors. Such construction has frequently been condemned in library literature.

Three more recommendations: Skidmore College reports that the tile walls in its stacks are easier to clean than conventional walls; (2) Albion College finds its master switch for stack lights very useful ; (3) St. Bonaventure College reports that the steel stack construction used in its library saved tons of steel.

\section{Equipment}

The desires of librarians concerning library equipment is best summarized by a table:

Exhibit and display facilities

Standard size furniture and shelves

Adjustable reference room shelves

Book return chutes

Built-in suction cleaner

Glass panels in study room doors

Unfavorable comments were made about the following types of equipment: ( I) door saddles, (2) cloakroom doors, (3) doors opening into corridors, (4) artificial fireplaces.

Most controversial is the matter of built-in equipment. Such equipment reduces flexibility and is, therefore, rejected by many. Particularly troublesome are built-in catalog cases as found in four libraries. In one library, periodical display shelves are built-in, making it impossible to use the room for anything else but a periodical room. Nevertheless, there were two librarians who did express a desire for built-in equipment to house maps, folio books, and displays.

\section{Conclusions}

It has long been a tradition among li- brarians to describe their new buildings in library periodicals at the time the buildings are completed. Such descriptions have rarely been followed by reports on the degree to which these buildings have proved satisfactory in operation. Follow-up reports, however, are necessary for the full appraisal of a building. The reports evaluating the libraries of the University of Colorado $^{2}$ and St. Bonaventure College ${ }^{3}$ may serve as models in this respect. Many more such reports should appear in print. Hanley has given the library profession some good descriptions, but her "criticism of the buildings is made in most cases entirely from floor plans and from section drawings, since it was impossible to visit each of the libraries in question."4 More recently, the meetings of the Cooperative Committee on Library Building Plans undertook critical discussions of existing library buildings. ${ }^{5}$

In order to determine the degree of bias in the answers, the responses were roughly divided into three groups: (I) favorable, (2) unfavorable, and (3) mixed (partly favorable and partly unfavorable). The librarians responding were divided into two groups: (I) those who had planned the buildings they now occupy and (2) those who had had no voice in the planning. A count showed that two-thirds or twentytwo of the librarians were now working in libraries they had not planned. Of these, seven made unfavorable comments, eleven were critical of some features, fifteen made mostly favorable comments. Of the eleven who now occupied buildings of their own

\footnotetext{
2 Ellsworth, Ralph E. "Colorado University's Divisional Reading Room Plan: Description and Evaluation." College and Research Libraries. 2: 103-09, March

${ }^{1}{ }^{3}$ Herscher, Irenaeus. "Friedsam Memorial Library." Library Journal 70: 22-23, Jan. I, 1945.

${ }^{4}$ Hanley, Edna Ruth. College and University $L_{i}$ brary Buildings. Chicago, American Library Associa

tion, 1939 , p. 10. Princeton Conference. June 12-14, 1946. Philadelphia, Stephenson-Brothers, 1947, p. 69. 85.
} 
planning, only two were partly critical and none made highly unfavorable comments. The conclusion may be reached that the degree of bias was not strong enough to invalidate the results of the survey, although some bias probably affected onethird of the responses.

It may be possible to obtain more impartial appraisals through personal visits by an expert. But such impartiality is likely to be offset by the fact that a visitor cannot get to know a building as well as those working in it every day. Properly financed, such an inspection trip might be very fruitful in verifying and supplementing the information gathered by mail. Certainly, many librarians are reluctant to express themselves freely for the record. Personal conversation will, therefore, reveal much that could not be secured in any other way.

Some of the respondents in the present survey obviously hesitated to express criticisms that might be considered too candid. Others asked that their answers be treated confidentially, or that their opinions be reported anonymously. However, the majority of librarians pulled no punches. Here are a few illustrations:

There are no unusual features about this building. It was built by an architect who knew little or nothing about libraries.

There are so many things wrong with this building, I really don't have time to detail them. It was planned by a two-bit architect.

Our present building is extremely inade- quate. ... There are no features which I would insist on having incorporated in any new building.

It is important to realize that many existing buildings are far from perfect. Equally important is a knowledge of building features that have stood the test of practice. Such knowledge, combined with the latest ideas on flexible design, should help college librarians to build better libraries. And there is no doubt that many new college library buildings will spring up in the near future. Between 1937 and 194 I, thirty-two new buildings were completed, but only three since $\mathbf{1 9 4 2}$. The war years evidently put a halt to new construction, and the increase in building costs is likely to retard construction for awhile. Wellesley College, Queens College, Colgate University, Goucher College, North Carolina Woman's College, Claremont College, and Bradley University are now working on building programs, not to mention the larger institutions. According to a survey by E. S. Evenden, thirty-two teacher colleges are considering erection of new library buildings at a total estimated cost of close to $\$ 7,000,000 .^{6}$ Library planners of tomorrow will be pioneers of new trends. But they will not fail to study the buildings of the past to learn from them what features to adopt and to avoid. The present survey was conceived as an initial effort in that direction.

'American School and Society 1946, p. 52.

\section{Change in Prices}

The subscription price of College and $R e$ search Libraries will be increased on Sept. I, 1948. The new rate will be $\$ 3.00$ per year to members of the Association of College and Reference Libraries; $\$ 4.00$ per year to nonmembers in the U.S., Canada, and Latin America; in other countries, $\$ 4.25$. This rate will apply to both new subscriptions and renewals.
The price increase was voted by the board of directors of the Association of College and Reference Libraries in order to meet higher publishing costs.

Remittances received before Sept. I, 1948, will be credited at the present rate of $\$ 2.00$ per year to members of A.C.R.L.; $\$ 3.00$ per year to nonmembers in the U.S., Canada, and Latin America; in other countries, \$3.25. 